\title{
Local Media and Media Convergence
}

\section{A Case Study of Suara Surabaya Radio as An Interactive Media Ido Prijana Hadi, Petra Christian University Surabaya, Indonesia}

\begin{abstract}
My aim in writing this paper is to describe that in this fast-changing world, media in Indonesia has undergone a rapid transformation. Digital technology continues to reshape the mass media landscape using internet technology. Internet brings a technical communication revolution, a fundamental change takes place in the structure of connections, artificial memories and the reproduction of their content. Internet technology has made communication much easier and less expensive. It has attracted many people and has penetrated into people's daily lives. The mass media also have accepted the internet. Almost all forms of traditional media (old media) in local media, such as radio, television, and newspaper have extended their work into this new field. The internet and the world wide web have both significantly influenced modern journalism.
\end{abstract}

In online media allows readers to enjoy browsing their product and service of contents, such as news feed, podcasts, desktop alert, news on mobile phones, PDA and others mobile devices. Online media offer not only text but also digital images, audio file, moving images (video), internet radio and internet $\mathrm{tv}$. The interactive features of the internet seemingly imply that online media have more advantages than traditional media forms (old media). So, the internet have dramatically evolved become new media with characteristic multimedia, hypertext, interactivity, archives, and virtuality. The most important structural new media characteristic is the integration of telecommunications, data communications and mass communication in a single medium - it is the convergence. It should be pointed out that the trend toward digital is affecting the various media and brings the local media in East Java to become a global media, where breaking news from Surabaya or anywhere in East Java is transmitted to around the world in a matter of minutes .

The research was carried out to find out how user reception on convergence media and local media on the site of Suara Surabaya.net (SS.net). And how to access subjective meanings that they have created based on their understanding on online media so far. The research is also 
interested in looking into user reception on information and communication technology based on its relevance with the selected theme namely discourses on global media in web site of Radio Suara Surabaya.

The result of this research that the texts on Suara Surabaya.net site is unique for Surabaya audiences who live in other countries because it can give them the user experience affection. The users can communicate with radio redactors (newsroom) too. Moreover, since they listen to online radio, they get the sense of excitement because they can see and get close with the announcer. Nowadays, the imaginative radio text has changed to the visual or impressive radio (intertextuality). It was long time ago that the radio just could be heard on ears, but now, it transforms to audio visual and newsroom that the audiences can see the broadcasting process. Interactivity based on users' perception claims that Suara Surabaya.net media can give reality exploration news by knowing and following recently news live at that time. SS net can improve value added and brand bonding power (station loyalty) of Suara Surabaya users wherever they are. Last of all, Suara Surabaya is not only tremendous radio but also has become community, which observes all kind problems of Surabaya and around society in daily lives as the publicsphere.

Keywords: convergence, local media, newmedia, oldmedia, journalism

\section{Introduction}

The development of new media ${ }^{1}$ truly has a tendency to a change in the process of media production, distribution, and usage. New media could not be separated from key terms, such as: digitality, interactivity, hypertextuality, dispersal, and virtuality (Lister, 2003: 13). In the concept of digitality, all process of digital media is transformed or saved in a form of number. Consequently, the out put in form of online source, digital disk, or memory drives, which are going to be transformed and received on monitor screen or 'hard copy'. The concept of interactivity has a tendency to the chance where the text in the new media capable giving users to 'write back into the text'. Different from the previous concepts, dispersal new media tends to the process of production, and media distribution be converted into decentralized and

\footnotetext{
1 "Some definitions of new media focus exclusively upon computer technologies while others stress the cultural forms and contexts in which technologies are used, for example, art, film,commerce, science and, above all, the internet. The relationship between technologies and cultural and media practices needs to be undertsood as linked at every stage, from invention to development and use". (Dewdney and Ride. 2006 : 8 \& 20).
} 
highly individualized. The limitation of new media frequently assumed to be equal to digital media. However, new media is more to the context and contemporary cultural concept from media practice than a set of technology itself (medium).

According to Mc Luhan (1997:7) medium is the message, so when it is being applied on the internet $^{2}$ or in a form of World Wide Web (WWW) it could be in a form of online news site. The analogy of Mc Luhan statement and the expansion of advanced information technology could be inferred that technology is the message. This technology produces new media. Not to mention exaggerating the effect of media, but with the existence of advanced technology, media is highly developed. Then, the writer in this context calls it as Information and Communication Technology. Media has been transformed to an interactive communication subject and has become a new friend for human being. Social interaction pattern, which is formed through media, has created a new space for human's life. The space where human could imagine and interact. Nevertheless, if it is connected to the context of network media (computer) which produces cyber community also has a contribution in forming a pattern of social relation without limitation, very broad, and transparent (Bungin, 2002).

According to Daniel Dakidae (Kompas, 28 Juni 2005) newspaper of modern industrial generation competes with television regarding to a quick service in presenting flabbergasted news, called scoop. The newspaper of post-modern generation has to compete with television, which has been transformed into digital technology. It has a possibility for multimedia application by using internet as the center, where each individual in a real-time could listen, hear, and read information from various sources approximately at the same time. The core meaning is newness or novelty. Unconsciously, the modern reader of newspaper changes the habit of quick browsing internet into the way of reading newspaper.

Internet as a new technology media also influences journalism transformation fundamentally (Pavlik, 2001). It is similar to ubiquitous news, global information access, instantaneous reporting, interactive, multimedia content, and extreme content customization. Internet period raises internet research, which focuses on three developments, for instance: the increase of

\footnotetext{
2 "The internet simply describes the collection of networks that link computers and servers together". (Lister, $2003: 165)$
} 
internet user $^{3}$, the growth of distinction between the content of online and off line media, and the relation change happened between media and its public (Pavlik, 2004: 442). The last focus is a public natural change because of communication technology and modern media. As a result, there is a shifting from the public into interactive media user (see Livingstone, 2003). This affects on public research; it would have better understanding on media and public transformation in term of integrated analysis perspective regarding to production, texts, and audiences in cultural contexts. Nowadays, audience research centers on the contexts of the use of media, and the interpretation of media content.

This could be someone's reflection for the consequence of social and technology change. Livingstone (2003) quoted from Alasuutari (1999:6) in constructionist view stated that "the audience" as a social phenomenon "out there" must be replaced by the recognition that the audience is "a discursive construct produced by particular analytic gaze". It is important to redefine the limitation of audience, which is changing in a relation between media organization and audience. Audience is moving into a change from local geographic community to community which has no limitation in terms of territory, politic, nationalism, ethnic, and other cultural limitations. People could access media wherever they are with no difference.

The object of this study is the text of Suara Surabaya Website (http://www.suarasurabaya.net) regarding its relation with users in East Java. Social change and cultural context also form the character of public media. The reason of choosing this media is because Suara Surabaya 100 $F M$ as local and conventional radio has applied the concept of news radio format and interactive information since 1995 (together with interactive redaction or gatekeeper with its motto: news, interactive, and solutive). It gains surprising attention from audience in both Surabaya and other areas near Surabaya until this present day. Conventional radio format is still being used and combined with information technology. Since 2000 when the era of digital news and cyberspace, Suara Surabaya Radio has developed internet online news, for instance: online news text, internet radio, radio on demand, video on demand, weather prediction, and

\footnotetext{
${ }^{3}$ The term "audience" must be used guardedly when discussing online media such as the internet. A better term "user", because what happens online is that people actively "do" something. People who go to websites are called "visitors". (Pavlik, 2004:443)
} 
exchange-rate currency. By applying internet ${ }^{4}$ technology and attractive editorial, Suara Surabaya enables its listener to access local news, which are chosen by themselves from various regions.

Radio internet, according to Dijk (2004: 153) is an interactive broadcasting which is actually a collective name concerning to digital audio broadcasting (DAB). Internet radio is a website, which distributes audiovisual program. It is also transmitted to regular broadcasting, where the main characteristic of its computer and internet user is individual that is in front of the monitor. Internet develops into new public space where people could get information promptly. Any kinds of information grow rapidly through internet. The remarkable thing here is that how each individual as the user in using internet as interactive media, and accessing information based on their need. Moreover, how the subjective meaning of the user, which they construct based on their understanding and the way they give significance regarding media convergence and journalism on Suara Surabaya.net (SS.net) media. It includes user reception on communication and information technology based on its relevancy with the chosen theme, that is discourse of local media which is successfully globalized on Suara Surabaya Radio (www.suarasurabaya.net).

\section{Review of Related Literature}

There are several main theories, were applied in conducting this research. Those theories are as follows:

\subsection{Internet as Journalistic Medium}

The emergence of problematic argument concerning internet as a medium whether as public media or inter-personal communication media is more probable caused by the characteristic of internet itself. It can be classified into public media or personal and inter-personal conventional media. It could be said that internet is a hybrid combination. It contains combination in which both media able to work as $\mathrm{CD}$ player and television equipment. Internet also functions as inter-personal communication medium, such as: e-mail. Jensen

\footnotetext{
${ }^{4}$ internet technology combined with increasing editorial sophistication, is empowering audiences to access local radio news of their own choosing, the Internet has created a 'technological' localness in addition to the 'geographical' localness we have previously understood to limit community membership (see Crissel and Starkey, 1998: 23).
} 
(1998: 46) makes a distinction of various media, which is called "pull" and "push". Traditional media, for instance: TV, radio, and film, have a characteristic of "push", in which media content is created by its media for the reader, listener, and viewer. In the other hand, the content of "pull" media (internet) is created by its user. Audience has more active role when surfing on the internet than on TV. The media content is shifting from universal into more personal, and publication cycle develops from periodic into up-to-date.

The improvement of technology conveys the influence to media content. According to Pavlik (1998) the news content on online edition (internet) has passed three stages, for instance: (a) online newspaper only repurpose content from their mother ship; (b) the journalists create original content and augment it with such additives as hyperlinks - with which a reader can instantly access another website; interactive features such as search engines, which seek out material on specific topics; and a degree of customization - the ability to choose what categories of news and information you receive; and (c) original news content designed specifically for the Web as a new medium of communication.

Journalistic as an activity to report a range of events happened in society, could not be separated from construction with certain perspective to be used as news materials by journalist; whereas news are report or announcement as regards an event which is informed by other person, either oral or written (Peter and Salim, 1991). In this context, the definition of news is the information serving regarding news which had happened, is happening, and will happen. That is why; the essence of World Wide Web from the previous justification is news, in which the reader reads it through browser. According to Glen Stovall (2004) on online journalism, there are dimension of flexibility, capacity, immediacy and permanent. Reporters could input their news report in various forms as information, for instance: full text, enclosing biography of the source, diagram, map, and picture as a tool to help the reader in understanding the news. Moreover, reporters could insert audio and video scenes, where the news takes place. This evident verifies flexibility of internet media, rather than printed and broadcast media. However, on the online journalism also has limitation placed on server computer in terms of data space, in which that information is saved and the length of time access. It is called as capacity limitation. 
Online journalism could launch instantaneous reporting in a form of breaking news event based on its context with coverage and global range. Immediacy has become the problem for the broadcaster in presenting their breaking news. Nevertheless, online journalism could be called as permanent because the reporters work for hours to finish news in a form of digital document, so that it could be saved on server computer for a long time with the same quality. It is diverse from printed, videotape, and audiotape medium which have more risk on quality degradation regarding the length of time. The quality of online information is more powerful, retrievable, but at the same time it is risky of duplication. This is because web is an open medium which equipped by high technology and full of networks.

The implementation of that concept, the writer attempts to observe the development of information and communication technology, which affect on the protest of news form change, from printed and broadcast into online news (e-news). Online news increases rapidly, not only in a form of text but also in a form of multimedia. Multimedia combines the text, audio, and video, which could be accessed whenever, and wherever people are. According to Fidler (1997) multimedia also known as a mixed media. On the other hand, conventional media (tv, radio, and printed media) which have synergy with internet in the convergence ${ }^{5}$ era, media is capable to increase value added and brand which is stronger and wider. The dimension of audience proximity geographically which becomes positive point (printed media, radio, and local TV), now becomes absurd on online media. Through webcasting on media online, it is able to get closer to someone's emotion concerning on their hometown and place of birth, similar to someone who goes abroad for study, work, or becomes foreign country citizen.

\footnotetext{
5 "The most important structural new media characteristic is the integration of telecomunications, data communications and mass communications in a single medium. It is the process of convergence. For this reason, new media are often called multimedia". (Dijk.2006 : 7).
} 


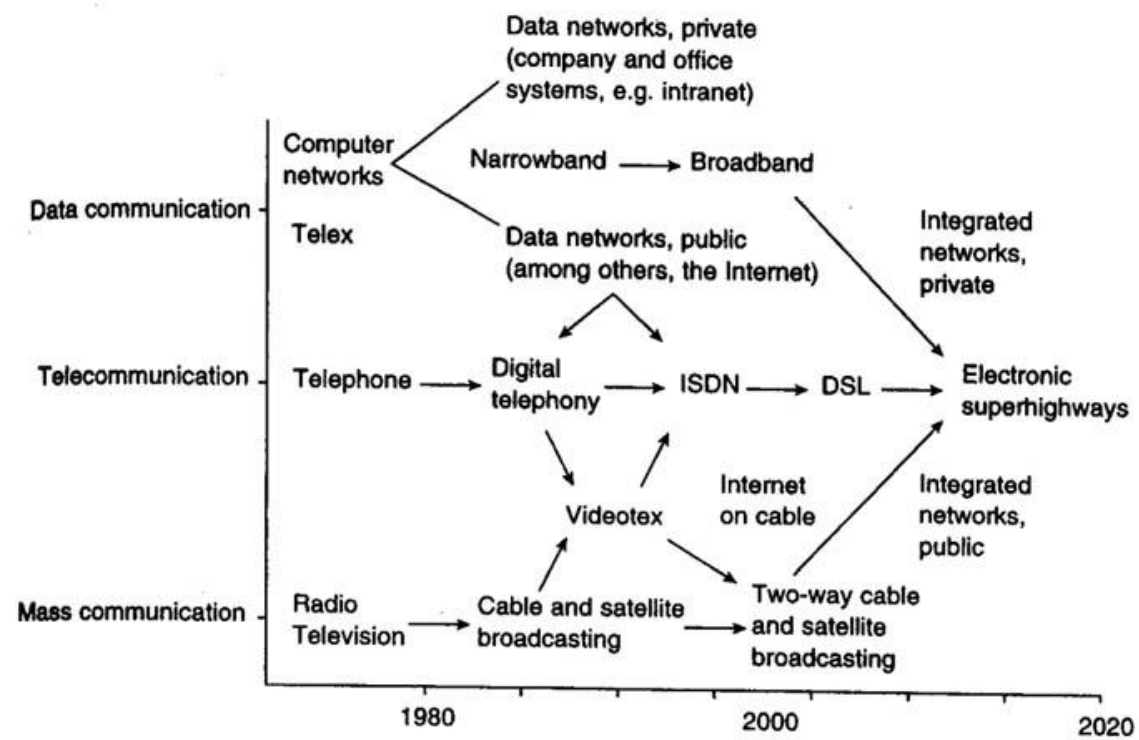

The Transmission Integration in Communication

(Source: Dijk, 2006:7)

The process of convergence to integration could be classified in one of the following levels: 1) infrastructure - as an example: combination of different transmision links and equipment for telephone and computer (data) communications; 2) transportation - as an example: internet telephony and TV web depend on cable and satellite television; 3) management - as an example: cable company develops telephone lines and a telephone company develops cable television; 4) service - as an example: combination of information and communication service on internet; 5) type of data - as an example: putting data in a form of voice, text, picture at the same time. In that picture, how public network and privat data, telecommunication and public communication at the same time create high-speed multifunctional network, called as electronic superhighway during 1990's. Recently, it is called as broadband (networks).

Furthermore, the information which is given by internet medium as information source similar to other medium, even faster, interactivity, hyperlinks text as information source and it does not depend on broadcast schedule and periode which could be found in newspaper (morning and afternoon). In addition, according to online media writer in Indonesia, which is based on settled institution, has shown amazing progress. It is not only printed media puts online information, but the news content has been designed specifically for web media as a communication medium, similar to Pavlik statement (1998). News web as an information source is no longer complentary but it sinergies with broadcast content, telecommunication 
(infrastructure and network), and computer, so it is able to provide online journalism with multimedia perspective. It is an advanced media revolution.

\subsection{Hypertext on Online Journalistic}

Lister (2003: 23) stated, "The type in hypertext is also a key term used to point to the novelty of new media and their assumed difference from old analogue media. Hypertext has come to describe a text which provides a network of links to others texts." On the other hand, Roland Barthes decribes an ideal text which is proper to the era and technology development, especially computer, is hypertext, where the text is composed by word and picture which are linked electrically with many lexia folder (paths). Then, hypertext could be called as link, node, network, web, and path. Moreover, Michael Foucault has similar opinion concerning about text in network and links terms. As a consequence, it creates what so called as hypermedia as the terms which stands for text in hypertext which includes audio-visual information, animation, and some other types of data. Since its success to connect text, for instance: picture, map, diagram, and voice as easy as delivering other verbal message, then hypertext becomes hypermedia. Hypertext becomes information medium which connects verbal and non-verbal message. Between hypertext and hypermedia able to change its role (Landow, George, The Definition of Hypertext and Its History as a Concept).

Internet, as a global computer link, is a technology which supports the improvement of ENews. Internet technology gives possibility to publish news by using Hypertext Markup Language (HTML)6. This format provides news (text, picture/photo, video, audion, and animation) digitally, so that the user could access from computer directly through web pages. Time and distance are no longer become the problems. Because of that, internet as journalistic medium has more possitive advantages compared to other type of public media. It is easy to access, produce, and distribute. Moreover, internet is cheap and world-wide range. For instance, BBC products and service (bbc.co.uk) provides news feed ${ }^{6}$, podcasts $^{7}$, desktop alert $^{8}$, news on mobile phones, Portable Digital Assistant (PDA) and other mobile equipments.

\footnotetext{
${ }^{6}$ News feed give the user easily to get the headline and current video without visiting website. Newsfeed a data format used for providing users with frequently updated content. Content distributors syndicate web feed, thereby allowing users to subscribe to it

${ }^{7}$ Podcasting lets you automatically receive the latest episode of your chosen programme as soon as it's available. With our current range of audio podcasts, you can take your favourite radio programmes with you on the move and listen wherever and whenever you like. Academics at the Community, Journalism \& Communication
} 
Document could classified as information. An article in newspaper is a document (printed document), similar to TV show program, a song or video is a document (electronic document). Therefore, a reporter in this digital era would face new terminology that is document. When reporter or editor make a news document for each media where they are working, they might think of the proper document format, whether printed or electronic. Electronic document which contains information could be changed from analog into digital format. Internet technology enables this thing happens. The digital document format could be access through internet, including picture/photo, audio, video, interactive web program instruction, and animation. All of them could be access through internet browser. In conclusion, hypertext could be said as the center of online news.

The emergence of online news, would insist printed media reporter to adopt broadcast style, where in broadcast world a reporter writes for video, still images and audio. Accordingly, the audience could hear on radio, as well as see it on television. Word in broadcast could complete information curiosity of the viewer and listener's mind. In contrast, printed media reporter has to use language to deliver its message to their reader. For that reason, the printed media reporter tries to create a "screen" on their reader's mind and build memory and imagination of the readers.

Similar to broadcast reporter, web media reporter has added e-text on their working system. E-text includes video, still images, animation, audio, and word for sure. Because of that, the challenge of being web reporter is being able giving new perspective so that thay could provide credible and trustful news for public. It affects on public perception which still assumes web media news as complementery new source and could be changed by applying professional working system, as the source of instant news.

Radio on demand facility is an audio clip documentation with certain duration, while video on demand is a visual clip news of reporter documention. Video on demand is usually in a form

Research group at the University of Texas at Austin in the USA are proposing a four-part definition of a podcast: A podcast is a digital audio or video file that is episodic; downloadable; programme-driven, mainly with a host and/or theme; and convenient, usually via an automated feed with computer software.

${ }^{8}$ Desktop alert give the user easily to get the current news headline which transmitted directly from media to desktop computer. 
of movie file or film which could be access by netter whenever the outlook is in a form of moving picture with audio which are taken directly from the place of event. When downloading video on demand, time duration which is needed is approximately one until two minutes, with the size of file between 500-1000 kilobytes. It includes Wireless Application Protocol (WAP) which is the nircable application facility which enables listener to get information wherever and whenever they are through cellular phone.

\subsection{Internet and Global Audience Discourse}

Internet communication system is essentially designed as a narrowcasting ${ }^{9}$ system, in which in one side users access and choose information based on their need; and another side internet which at the beginning could only provides full service web information becomes a server which provides information based on its speciality. This fact could not be separated from internet users who become more selective in accessing and choosing proper information. Each individual wherever they are could access internet to download document in a form of text, picture, audio, video, and other type of documents. Morover, internet users could discuss with other users on online discussion facility. As a result, cyber reality becomes the characteristic of online media.

Conventional media discourse (radio) which develops to online media (internet) through website becomes cenvegence. The integration between conventional, telecommunication, and information technology (multimedia and internet) which make information access easily. It could be called as superhighway information. In addition, media convergence has changed communication from to global. As the effect, globalization through internet enables instant communication and destroys privacy boundary. Manuel Castells (Street, 2001: 179) stated, "We live, not in global village, but in 'customized cottages globally produced and locally distributed".

Discussing about online compared to conventional media, from the perspective of media research is in fact on communication capacity. Online audience has capability to give feedback to the media directly with interactive relation. On the other hand, the process of communication of conventional media audience is linear, although there have been many

\footnotetext{
${ }^{9}$ Barry Cox argues that digital television 'will intensify the fragmentation of audiences...broadcasting becomes narrocastings - the distribution of content to small, niche audiences. (Street, John, 2001:178).
} 
media which open interactive programs for its user through feedback mechanism. Both the audience of online and conventional media are active, but online audience are more active than conventional media audience. Online audience becomes a full participant.

Whereas, the interactivity on online journalism is a relation between reporter and consumer and it is a meaningful relation with a new form of journalistic. According to Williaam, Rice, and Rogers 1998 (Severin and Tankard, 2001: 370) interactivity as "the degree to which participants in a communications process have control over, and can exchange roles in their mutual discourse”. Thus, user is the controller of communication. One of studies concerning internet operation finds six interactivity dimentions: 1) internet ables to provide information rather than persuation; 2) internet user takes control; 3) most of the activities done by the user (active); 4) two way communications; 5) flexible time of communication compared to conventional media (printed media) which has certain schedule, and 6) communication happens on a place which is "created" by user (Roger, 1998).

\section{Methodology}

This research was qualitative research that use constructive interpretive paradigm with case study method (single case) and reception analysis. Reception analysis is concerned with the differentiate between media and audience discourse textual analysis that had the interpretation result focus on contexts such as cultural setting and context from other media (Jensen, 2003 : 139). Audiences were seen as the part of interpretive communitive who always active in assuming the message and producing that meaning, not merely passive agreed to all information from mass media production (McQuail, 1997:19).

The study of reception analysis tried to know how audiences understand, interpret the meaning of message based on story of life and the opinion in doing interaction and consume the content online media. The schema of mediator understanding toward the media content that integrated on daily life was a long process accumulation into adorable experience for mediator itself, included understanding of interactivity. Then, the researcher conducted facts or assumptions about bracketing that was understood by audiences about online media discourse and socialization. Thus, by doing interview, researcher got audiences confession and experiences while they accessed Suara Surabaya.net. 
The target of this research was two subjects, Suara Suarabaya.net media and mediators. In here, mediators were the users of Suara Surabaya.net site who were logging on www.suarasurabaya.net site and doing the connection through feedback online mechanism based on database of Suara Surabaya as existing netter and target market. The researcher did indepth-interviewing as his technique of collecting the data. Since the instrument of this research was the researcher himself, so he also did oral interview by phone for mediators in Indonesia and email for mediators in other countries. The result of in-depth-interview was interpreted qualitatively to answer research question.

For analysis, firstly, the researcher did triangulation data by analyzing the confession of mediators to find the meaning behind the data. Secondly, he used conceptual theoretic in review literature as the tool to analyze the data. The researcher gave mediators option to choose the appropriate concept limitations or intertextuality to interpret the text on Suara Surabaya.net.

\section{Findings}

Interviewing result with the creator of Suara Surabaya.net online media state that the development of internet radio and online journalistic is needed in this global era as development demand. Media must close to the audiences in where they are. Audio and video information can be saved in digital then it make listener easier to seek archive file. Since radio cannot be limited in geographical and frequency anymore, it must go online with internet technology in order to the listeners or users can access the information efficiently. Also, it can improve value added and brand bonding power (station loyalty) of Suara Surabaya users wherever they are. Last of all, Suara Surabaya is not only tremendous radio but also has become community which observes all kind problems of Surabaya and around society in daily lives as the publicsphere.

The result from this research is audiences' representative of Suara Surabaya media that since 2002 has developed cyberspace era through Suara Surabaya.net. The mediators are 33-56 years old and have different background in race, culture, environment, education, profession and intensity in access Suara Surabaya.net. There are several intensities of audience in access Suara Surabaya.net such as, first, on a day can access every 30 minutes; second, on a week 
can two until three times or on a month six times to access this net; third, one time on a month; and last, just access it if mediators needed the information. The mediators' reasons in access Suara Surabaya.net are because they need information about Surabaya environment and want to up date the news that can be gotten from other media.

Besides that, Surabaya mediators who live in other countries have strong memorable and emotional affection as Surabaya citizen about Surabaya environment such as the condition of traffic jam in several crowded streets and the weather. Implicitly, they turn back to the past memory when stayed at Surabaya from accessing every hyperlink on Suara Surabaya.net. It is pleasant movement audiences do in every night until mid-night to access the news directly or even can give commands on Suara Surabaya.net email.

\section{Texts and Production: A Media Convergence Meaning on Users Mind}

The texts on Suara Surabaya.net site is unique for Surabaya audiences who live in other countries because it can give them the user experience affection. By browsing the site and user interface affection through hyperlinks and feedback process, mediators can insert critiques, comments, questions as the discussion. The users can communicate with radio redactors (newsroom) too. Moreover, since they listen to online radio, they get the sense of excitement because they can see and get close with the announcer. Nowadays, the imaginative radio text has changed to the visual or impressive radio (intertextuality). It was long time ago that the radio just could be heard on ears, but now, it transforms to audio visual and newsroom that the audiences can see the broadcasting process.

The convergence of broadcasting media by internet creates global audience. Audiences assume it is the efficiency of access information without go to the specific place. Whenever and wherever they are, they can get new news. There is a facility of accessing headline news for mediators in accessing news by video streaming mobile. Therefore, for mediators who are in other Surabaya areas and have relatives or families in Surabaya still can search out Surabaya environment news by hyperlink Rubrik Berita Terkini (current news) and Kelana Kota on Suara Surabaya.net.

Mediators choose Rubrik Berita Terkini as the essential choice to be accessed because it program notifies recent events or issues national or international about politics, business 
economy, sport until technology. So, mediators believe that Rubrik Berita Terkini program is the quickest and easiest access to catch information. It is obliging for audiences in Duri, Riau that usually get news on evening newspaper, but now, they can get actual information by surfing Rubrik Berita Terkini on Suara Surabaya.net.

Thus, since mediators as the workers, they get free access internet facility to explore and inform news from their company. Besides that, mediators argue that the news on television is not effective enough since it showed with certain show time. It means, television still adopt informing news based on showed time periodic. On the other hand, online media always up date new news or headline news anytime before it is notified on newspaper. It is a unique phenomenon because it creates new habit for audiences in acquiring information. Mediators just link on Suara Surabaya.net, can check email, and also can get actual and clear news which easy and quick access at the morning before they start their activities. Mostly, they get information about Surabaya street environment such as traffic jam in specific places and the alternative way to pass it.

Furthermore, Kelana Kota is the foremost program and mediator also accesses it since it is the core of Suara Surabaya radio program. It is documented on WebNews and notifies local, national, international news content that have effect with economy, social and politik on Surabaya and East Java. Mediators choose to link this site because the information on it is more interesting than other online media. There are some photos, the voice from online radio and audio on demand and video on demand which can give feel sense of belonging because of the sense of shared identity and values. They can feel close to their hometown situation and make them always link it even they are in other Surabaya areas.

One mediator who had lived in Glasgow, England to study says that listening Suara Surabaya online radio from computer, blackberry, nokia (suarasurabaya.net/mobile) in his country is like drive a car on Surabaya street completed with Surabaya traffic news. It is undoubted that long distance with families on Surabaya can arouse homesick feeling, but Suara Surabaya online radio can make this mediator get close with brand bonding to families and Surabaya environment. Commonly, this mediator accesses this media at the night or spare time at the office. 
Another two Indonesia mediators who stayed in other countries have sophisticated experience about Suara Surabaya online radio. There are one mediator who has stayed in Sydney, Australia since 2002 and other who has stayed in Massachusetts, USA since 2001. While they are tuning up online radio in the long distance from Surabaya, they feel "it's close to my hearth and ears". The researcher finds emotional affection to their relatives or families and the situation or environment in Surabaya. Mediators see Suara Surabaya online radio as the best radio to inform the Surabaya news and Kelana Kota program is their meal.

Interactivity based on users' perception claims that Suara Surabaya.net media can give reality exploration news by knowing and following recently news live at that time. Moreover, mediators feel impressive in hearing numbers of commends from the Suara Surabaya listeners in live. It means there is no editing news from the media. Mediators sometimes follow online discussion about social, economy and business topics with the creator and other listener on this net. By discussing those topics in this media, according business mediators, it can improve the actual news and knowledge about business in Surabaya and Indonesia as their obligation to follow business issues. However, even thought Suara Surabaya.net has Economy Business program to inform business rules from accumulation reports and discussions, business mediators feel not informed enough about business issues. They think this media inform Surabaya economy business only so they should link to other sites to get more information.

Next, IT mediators claim that accessing internet from their house and office is easier than accessing other media like phone call. It means, all information they get from internet. E-mail or yahoo messenger (chat tools on internet) is their meal since they work with computer all the day. As the heavy users, IT mediators have habit to bookmark some favorite sites as their daily access and one of those is Suara Surabaya.net.

From those mediators' opinions that the researcher found, communication technology can make something from local to global. Also, listeners feel impressive while online radio complete their information source. Conventional radio (based on frequency) in internet era is demanded can empowerment or innovate listener to be more critical. Nowadays, listener is going to access media interactive and tendency mobile in searching out quick, neutral and flexible information. They can access it in everywhere globally without any cage of 
geography, place and time dimensions. Modern human in internet era not only life in global village but also become the part of audience global that can share local information to global. It means, audience is a world bridge.

Editorial issues on newsroom radio become interesting for all listeners. Multimedia convergence technology and internet cause information stream goes fast. Media is not merely followed publishing time periodically and limited broadcasting time for specific distance. On the other hand, in Indonesia nowadays, the regulation of broadcast using internet is looked unregulated yet for community, companies, institution. Thus, they create website or conventional media free to spout their broadcast with internet technology.

\section{Conclusion}

Based on clarification above, the researcher conclude that the users' understanding and interpretation about media convergence and journalism on Suara Surabaya.net is interesting because it can give user experience by browsing the layout and user interface which give sophisticated experience. Suara Surabaya.net offers interactivity from hyperlinks and feedback (Critiques, Comments, Question) mechanism that involve users on it. Users can open communication with redactors. Moreover, by listening online radio, it give the sense of excitement because the listener can see and get close with announcer. The imaginative radio text has changed to the visual or impressive radio (intertextuality). It was long time ago that the radio just could be heard on ears, but now, it transforms to audio visual that quick, cheap and fast.

Suara Surabaya.net online media is portal news of informing local news in Surabaya, East Java and national that is packaged on audio document from believable news source (quick and cheap) in order to complete mediators' information with quick and detail. Suara Surabaya.net has connected (become connector) users with their community and tried to create society with critical mindset, and cares on making lovely open culture from many sectors as skateholders on citizen. Broadcast media convergence with internet creates global audience. Convergence is recognized as the easiness of getting new information in everywhere, whenever they are. There is a facility to access headline news rapidly with video streaming. Internet 
communication technology on radio can change something from local to global. Also, listener can complete their information source by accessing virtual radio. 


\section{References}

Alasuutari, Pertti. (ed).(1999) Rethinking the Media Audience. London: Sage

Baran, Stanley J. (2003) Mass Communication Theory; Foundations, Ferment, and Future, $3^{\text {rd }}$ edition. Belmon, CA : Thomson

Bungin, Burhan; New Media dan Perkembangannya; Konstruksi Sosial Telematika dan Inovasi Media Baru, Seminar dan Lokakarya "Being Local in National Context : Understanding Local Media and Its Struggle”, Universitas Kristen Petra, di Surabaya 14 Oktober 2002.

Crissel, Andrew and Starkey,Guy. (1998) News on Local Radio; Local Journalism and Local Media, Making the Local News. Edited by Bob Franklin. New York: Routledge.

Dewdney, Andrew., and Ride, Peter. (2006) The New Media Handbook. London: Routledge.

Dijk, Jan Van. (2006) The Network Society; Social Aspects of New Media. $2^{\text {nd }}$ edition. London: SAGE Publications Ltd.

Craig, Richard. (2005) Online Journalism; Reporting, Writing and Editing for New Media.Thomson

Effendy, Onong Uchjana. (2005) Komunikasi dan Modernisasi, Bandung: Mandar Maju Fidler, Roger. (1997) Mediamorphosis, Understanding New Media. Thousand Oaks (calif): Pine Forge Press,

Ibrahim, Idi Subandi. (2004) Sirnanya Komunikasi Empatik; Krisis Budaya Komunikasi dalam Masyarakat Kontemporer: Bandung : Pustaka Bani Quraisy.

Jensen, Jens Frederik. (1998) Communication Research after The Mediasaurus? Digital Convergence, Digital Divergence. The Media Lanscape in Transition. Research on New Information Technology. In Nordicom Review 1/98. Nordicom, Goterborgs Universitet.

Landow, George; The Definition of Hypertext and Its History as a Concept, http://www.thecore.nus.edu.sg/landow/cpace/ht/jhup/history.html\#1, accessed 14 February 2005.

Lister, Martin. (2003) New Media : A Critical Introduction. London: Routledge Livingstone, Sonia (2003) The Changing Nature of Audiences, from the Mass Audience to Interactive Media User. A Companion to Media Studies, Edited by Angharad N. Valdivia. Malden: Blackwell Publishing. 
Muljono; Sistem Berita Elektronika di Intranet Universitas Pelita Harapan Menggunakan Lotus Notes dan Domino, Jurnal Ilmiah Universitas Pelita Harapan, LPPM-UPH Menara UPH - Lippo Karawaci - Tangerang.Vol. 4/No.7 August 2001, p. 37.

McLuhan, Marshall. (1999) Understanding Media; The Extension of Man. London : Routledge.

McQuail, Denis. (1987) Teori Komunikasi Massa; Suatu Pengantar. Jakarta. Edisi Kedua: Erlangga.

McQuail's, Denis. (2001) Mass Communication Theory. London. $4^{\text {th }}$ edition: SAGE Publications, Inc.

Muslimin, Totok., dan Djuroto. (2002) Teknik Mencari dan Menulis Berita. Semarang: Dahara Prize, Effhar Offset.

Oetama, Jacob. (2001) Pers Indonesia Berkomunikasi dalam Masyarakat Tidak Tulus: Percetakan PT. Gramedia. Jakarta, Oktober.

Online News Association [ONA], Digital Journalism Credibility Study, http://www.journalists.org/Programs/Study.htm, accessed 7 February 2002.

Pavlik, John V and Shawn McIntosh. (2004) Converging Media, An Introduction to Mass Communication. Boston : Pearson Education, Inc.

Pavlik, John V. (2001) Journalism and New Media: Columbia University Press

Pavlik, John V. (1998) The Future of On-Line Journalism, chapter in Wickham, Kathleen, On-Line Journalism Perspective: CourseWise Publishing, Inc..

Perebinossoff, Philippe. (2005) Programming for TV, Radio and The Internet, Strategi, Development and Evaluation. Second Edition : Focal Press. Elsevier Inc Rahmat, Jalaludin. (2002) Metode Penelitian Komunikasi. Bandung: PT.Remaja Rosdakarya. Salim, Peter dan Yenny Salim. (1991) Kamus Bahasa Indonesia Kontemporer. Jakarta: Modern English Press.

Scanlan, Christopher; The Web and The Future of Writing, Poynter Reporting and Writing Group Leader, http://www.poynter.org/centerpiece/062100.htm, accessed 20 July 2002 Stovall, James Glen. (2004) Web Journalism of a New Medium. University of Alabama: Pearson Education Inc.

Straubhaar, Joseph dan Robert La Rose. (2002) Media Now: Communication Media in the Information Age: Australia: Wadsworth

Street, John. (2001) Mass Media, Politics and Society. New York: Palgrave 
Severin, Werner J and James W. Tankard. (2001) Communication Theories; Origin, Methods, and Uses in the Mass Media. 5th Edition. University of Texas at Austin: Addison Wesley Longman Inc.

Piliang, Yasraf Amir. (2004) Dunia yang Dilipat; Tamasya Melampaui Batas-Batas Kebudayaan. Yogyakarta : Jalasutra 